\title{
HEALTH RISK ASSESSMENT IN RELATION TO HEAVY METALS POLLUTION OF WESTERN MEDITERRANEAN SEA, EGYPT
}

\author{
Amany EI Sikaily \\ Environmental Division, National Institute of Oceanography and \\ Fisheries, Alexandria, Egypt
}

Keywords: heavy metals, risk assessment, Mediterranean Sea sediment pollution

\begin{abstract}
Concentrations of heavy metals (Mn, $\mathrm{Fe}, \mathrm{Zn}, \mathrm{Cu}, \mathrm{Pb}, \mathrm{Co}, \mathrm{Cr}, \mathrm{Ni}$ and $\mathrm{Cd}$ ) were measured in the sediment collected from 7 stations along west Mediterranean Sea (Sidi- Krir ; open sea, east \& west Sidi Krir, Sidi Barrani and El-sallum l, 2,60m). Also, health risk has been performed in relation to recreational activities at these places, using an exposure assessment model. The results of this study indicated a general moderate or absence of serious pollution in these places due to heavy metals; whereas the concentration of elements found could be mainly due to geological and atmospheric sources. However, the health risk evaluation is useful as a screening methodology for assessing the urgency of sediment remediation actions.
\end{abstract}

\section{INTRODUCTION}

In the last decade, studies on the occurrence, distribution and accumulation of toxic pollutants have significantly increased, mainly due to the global effects of environmental pollution on aquatic ecosystem. Heavy metals have been shown to be an important group of water contaminants, because of their high toxicity and persistence in all aquatic systems (Oscaramin, 1996). Metal contaminants can enter the environment in excess of natural amounts from industrial and mining effluents, from the combustion of fossil fuels, discharge of sewage and sewage sludge from fertilizer and pesticide residues förstner and Wittmann, 1979). The potential impacts of heavy metals are generally restricted to locations adjacent to major cities or industrialized areas on the coastal fringe (Batley, 1995) and to site draining areas of intensive agriculture. Once introduced into marine environment, heavy metals have the potential to affect sediment 
nutrient cycling, cell growth and regeneration as well as reproductive cycles and photosynthetic potential of marine organisms (Peters et al., 1997). Heavy metals such as $\mathrm{Pb}, \mathrm{Cd}$ and $\mathrm{Zn}$ are good markers of contamination from human activity (Ravanelli et al., 1997). Oral ingestion of contaminated soils and dust by children is the principle cause of lead absorption (Xintaras, 1992). Moreover, Cd is contained in some phosphate-based fertilizers; such sources could constitute a major source of $\mathrm{Cd}$ absorption by humans. In addition, sewage sludge from wastewater treatment can contain significant quantities of $\mathrm{Cd}$. It is also a side product of zinc smelting (Tran, 2002). The leachable metal fraction is defined as the anthropogenic fraction of metals involved with the sediment particle. Diluted acids have often extracted the leachable fraction (Malo, 1977; Salomons and Förstner, 1980; Hamilton et al., 1984; Queirazza and Guzzi, 1987; Angelidis and Aloupi, 1995). The objective of this study is to determine concentration and distribution of some metals in a series of sediments collected from different sections along Mediterranean Sea, to monitor environmental changes and their health risk.

\section{MATERIAL AND METHODS}

Sediment samples were collected during spring 2003, from seven stations along the west cost of Mediterranean Sea (Sidi-Krir open sea, west Sidi Krir, east Sidi Krir, Sidi Barrany and Sallum at 1, 2 and $60 \mathrm{~m}$ depth) (Fig. 1). The homogenized samples were stored in clean polyethylene jars. In the laboratory, the sediment samples were separated into sub-samples for the respective treatment procedures.

\section{Determination of total heavy metals}

The sediment samples were dried at $105{ }^{\circ} \mathrm{C}$, sieved and subsequently ground in a mortar. From each dried sample, $0.2 \mathrm{~g}$ of sediment was completely digested, using $\mathrm{HNO}_{3}, \mathrm{HF}$ and $\mathrm{HClO}_{4}$ (Trefry and Mettz, 1984). The final solution was diluted to $25 \mathrm{ml}$ with distilled deionized water. Metal concentrations were determined, using Perkin-Elmer model atomic absorption spectrophotometer (AAS). Reagent and blanks were analyzed to check for metal contamination during processing.

\section{Determination of leachable heavy metal}

An aliquot of $0.5 \mathrm{~g}$ of dry sediment was treated with an excess of $160 \mathrm{ml}$ of $0.3 \mathrm{~N} \mathrm{HCl}$ and stirred for two hours at room temperature, the suspension was filtered on Nuclepore $0.4 \mu \mathrm{m}$ polycarbonate 
filters, previously treated with $6 \mathrm{M} \mathrm{HCl}$ and ultra pure water, then with $1 \mathrm{M} \mathrm{CH} \mathrm{CO}_{2} \mathrm{NH}$ and later with $100 \mathrm{ml}$ ultra pure water. The analytical procedure has been validated on a certified sample of IAEA SD-M-2/TM marine sediment which was totally digested by $\mathrm{HNO}_{3} / \mathrm{HF} / \mathrm{HClO}_{4}$ solution. Results obtained for the IAEA-SD-M2/TM marine sediment are given in Table (1). All metal concentrations were within acceptable ranges.

\section{Risk assessment}

For quantification of exposure in relation to sediment contamination by heavy metals, a multiple pathway exposure model. (SEDISOIL) was used (Bocking et al., 1996). The model was developed by the National Institute of Public Health and Environmental Protection and includes six exposure routes: the ingestion of sediment, surface water included suspended matter, dermal contact via surface water and sediment, and fish consumption. The following equations were incorporated into the model to calculate total exposure.

Ingestion of contaminated sediment $\left(\mathrm{mg} \mathrm{kg}^{-1}\right.$ day $\left.^{-1}\right)$

$=(\mathrm{Cs} \times \mathrm{IRs} \times \mathrm{EF} \times \mathrm{AF}) \div \mathrm{BW}$

where $\mathrm{Cs}=$ Concentration of the contaminant in sediment $\left(\mathrm{mg} \mathrm{kg}^{-1}\right.$ $\left.\mathrm{day}^{-1}\right) ; \mathrm{IRs}=$ Ingestion rate of sediment $(\mathrm{kg} \mathrm{dw} /$ exposure day), $\mathrm{EF}=$ exposure frequency (days $/ 365$ days), $A F=$ Absorption factor (unitless), and $\mathrm{BW}=$ Body weight $(\mathrm{kg})$

Dermal contact with contaminated sediment $\left(\mathrm{mg} \mathrm{kg}^{-1} \mathrm{day}^{-1}\right)$ $=(\mathrm{Cs} \times \mathrm{SAs} \times \mathrm{AD} \times \mathrm{Ass} \times \mathrm{Mf} \times \mathrm{EDs} \times \mathrm{EF} \times \mathrm{AF}) \div \mathrm{BW}$

where, $\mathrm{SAs}=$ dermal surface area for sediment exposure $\left(\mathrm{m}^{2}\right), \mathrm{AD}=$ dermal adherence rate for sediment $\left(\mathrm{mg} \mathrm{cm}^{-1}\right), \quad$ Ass $=$ dermal absorption rate for sediment (liter/hour), $\mathrm{Mf}=$ matrix factor (unitless), and $\mathrm{EDs}=$ exposure duration from dermal exposure to sediment (hour/day)

Daily exposure is calculated according to the following equation $\left[\left(6 \times\right.\right.$ daily exposure $\left.\left._{\text {child }}\right) \div 70\right]+[64 \times$ daily exposure adult $) \div 7$

If the hazard index is below 1 , no health risk may occure

\section{RESULTS AND DISCUSSION}

The analysis of environmental matrices such as water or sediments provides a picture of the total contaminants load rather than of that fraction of direct ecotoxicological relevance. (Campanella et 
al., 2001). Table (2) shows total and leachable contents of $\mathrm{Mn}, \mathrm{Pb}$, $\mathrm{Zn}, \mathrm{Fe}, \mathrm{Cd}, \mathrm{Cu}, \mathrm{Co}, \mathrm{Cr}$, $\mathrm{Ni}$ in sediment samples collected from seven stations along Mediterranean Sea weastern coast. The sediment values for total metals were 26.85 for $\mathrm{Mn}, 60.05$ for $\mathrm{Pb}, 76.6$ for $\mathrm{Zn}$, 222.5 for $\mathrm{Fe}, 5.14$ for $\mathrm{Cd}, 12.3$ for $\mathrm{Cu}, 27.73$ for $\mathrm{Co}, 20.06$ for $\mathrm{Cr}$ and $38.98 \mathrm{mg} / \mathrm{kg}$ for $\mathrm{Ni}$. The corresponding values of leachable metals were 24.73 for $\mathrm{Mn}, 51.66$ for $\mathrm{Pb}, 17.2$ for $\mathrm{Zn}, 190.06$ for $\mathrm{Fe}, 4.43$ for $\mathrm{Cd}, 8.25$ for $\mathrm{Cu}, 17.27$ for $\mathrm{Co}, 17.49$ for $\mathrm{Cr}$ and $29.11 \mathrm{mg} / \mathrm{kg}$ for $\mathrm{Ni}$. Mann-Whitney U-test analysis showed a significant difference between total and leachable metals $(\mathrm{Zn}, \mathrm{Co}, \mathrm{Ni}) \mathrm{P}$-values were 0.004 , $0.004,0.003$, respectively. The total concentration of $\mathrm{Zn}$ in the sediment was $76.6 \pm 23.59 \mathrm{mg} / \mathrm{kg}$. The contamination of coastal regions including estuaries and marginal seas are attributed to a number of causes (Förstner et al., 1978). The most important are direct input of effluents from industries and communities dumping of wastes from ships and through atmospheric fallout. The concentration of leachable $\mathrm{Zn}$ (non-residual $\mathrm{Zn}$ ) shows the same pattern as the total $\mathrm{Zn}$ in sediments, indicating that most of $\mathrm{Zn}$ is in a leachable form $\left[\mathrm{Zn}(\mathrm{OH})_{2}\right]$. This indicates that $\mathrm{Zn}$ is derived from anthropogenic source (El-Sayed, 1988). Meanwhile, the total $\mathrm{Cu}$ was $12.3 \mathrm{mg} / \mathrm{kg}$ which is lower than at any places along Alexandria coastal region. The distribution of leachable $\mathrm{Cu}$ shows the same pattern of total sediment, which seems to be affected by the anthropogenic activities. Therefore, it is the non-residual metal concentration, which truly reflects the extent to which the sediments have subjected to heavy metal pollution (Chester, 1981; Chester 1985). On the same manner, the lowest concentration of total $\mathrm{Pb}$ in this area indicates that this area receives little or no flow or sediment. This indicates that this area is protected from industrial inputs.

The Concentration of total and leachable $\mathrm{Pb}$ decreases in the sea ward direction, which may be due to the remoteness from the source of pollution as well as the desorption of $\mathrm{Pb}$ from sediment facilitated by increasing salinity (De-Groot et al., 1976). On the other hand, a higher concentration of $\mathrm{Cd}$ was found at this region than that found by Khaled (1997) (Table 3). The increased concentration of $\mathrm{Cd}$ in the sea ward direction may be due to carbonate content in the sediment, where $\mathrm{Cd}$ is the only metal which exhibits enrichment as carbonate. The association of $\mathrm{Cd}$ with carbonate was reported by many investigators (Deure et al., 1978; Förstner et al., 1981), who found that $\mathrm{Cd}$ is usually co-precipitated with organic minerals and the occurrence of $\mathrm{Cd}$ in sediment is mainly due to the formation of 
$\mathrm{CdCO}_{3} . \mathrm{Cd}$ in sediment is less mobile than other metals due to the formation of $\mathrm{CdCO}_{3}$ phases in alkaline media. Also, the highest concentration of $\mathrm{Cd}$ may be due to the use of $\mathrm{Cd}$ as pigments in ship painting (Moore et al., 1985). The concentration of $\mathrm{Mn}$ in sediment may reflect atmospherically transported material (Voutsinou et al., 2000). Meanwhile, the concentration of $\mathrm{Ni}$ may be due to the dissolved load by natural chemical weathering process (Gaiero et al., 2001). Grain size analysis indicated that the pollution at this region may be due to geological changes (Table 5).

\section{Risk assessment}

The results of this health risk assessment indicated that sediment contamination by $\mathrm{Cd}, \mathrm{Zn}$ in this area may present a health hazard, if the risk was calculated on the basis of the standard exposure model. Dermal absorption depends on the dermal absorption rate for the individual compounds. Ingestion of sediment was considered an important route of exposure if exposure, was calculated based on location-specific input data. However, no specific data on the sediment ingestion rate by children and adults were available for risk assessment purposes. Therefore, sediment ingestion rates were based on soil ingestion rates in relation to contaminated sites. Other exposure routes were of minor importance in relation to total exposure levels for heavy metals, while swimming contributed less than $1 \%$ to the total average exposure levels.

\section{CONCLUSION}

This study showed that the level of heavy metals were low in most of sampling station. The application of the standard exposure model, which is currently used by the Dutch government, indicates that sediment contamination by $\mathrm{Zn}$ and $\mathrm{Cd}$ may cause a health 'risk in relation to recreational activities. In general, exposure risk assessment of present type can be used for screening purposes to identify important exposure pathways and to determine the urgency of sediment remediation actions.

\section{REFERENCES}

Amin, O. (1996). Heavy metal concentrations in litteral sediments from the beagle channel, Lierra Del Fuego, Argentina. Environ. Monit. and Ass. 41:219-231. 
Angelidis, M. O. and Aloupi, M. (1995). Mar. Poll. Bull., 31: 273276.

Batly, G. E. (1995). Heavy metals and tributylin in Australian coastal and estuarine waters. In the state of the Marbie environment, Report for Australia Technical Annex 2 pollution, eds. L. P. Zann and D. C. sutton pp. 63-72 Great Barrier Reef Marine Park Authority Townsville.

Bockting, G. J. M. ; Koolenbrander, J. G. M. and Swartjes, F. A. (1998) SEDISOIL. Estimation of human exposure to sediments [in Dutch]. Rpt. No. 715810011. Bilthoven, the Netherlands: National Institute of Public Health and the Environment.

Campanella, L. ; Conti, M. E. ; Cubadda, F. and Sucapane, C. (2001). Trace metals in seagrass, algae and molluscs from an uncontaminated area in the Mediterranean. Environ. Poll.. 111: 117-126.

Chester, R. and Voulsinou, F. G. (1981). Mar. Poll. Bull. 12: 84-91.

Chester, R. ; Kudoja, W. M. ; Thomas, A. and Towner (1985). J. Environ. Poll. Ser. B., 10: 213-238.

De-Groot, A. J. ; Salomons, W. and Allersma, E. (1976). "Estuarine chemistry", Burton, E. J. D. Acadamic press, London, New York, San Francisco, Chapter, 5:131-157.

Deure, R. ; Forstner, U. and Schmoll, G. (1978). Geochim. Cosmochim. Acta., 42: 425-427.

El-Sayed, M. Kh. ; El-Wakeel, S. K. and Rifeet, A. R. (1988). Oceanogr. Acta., 11: 1-11.

Förstner, U. ; Müller, G. and Stoffers, P. (1978). Proceeding of a UNESCO/ SCOR workshop held in Melreux, Belgium. pp. 49-69.

Förstner, U. and Wittmann, G. T. W. (1979). Metal pollution in the aquatic environment, Springer-Verlag, Berlin. pp 30-61. 
Förstner, U. and Wittmann, G. T. W. (1983). Metal pollution in the aquatic environment. $2^{\text {nd }}$ ed. Chapter D, Springer-Verlag, Berlin Heidelberg, New York, Tokyo, 486 pp.

Gaiero, D. M. ; Probst, J. L. ; Depetris, P. J. ; Lelyter, L. and Kempe, S. (2001). Riverine transfer of heavy metals from Patagonia to the southwestern Atlantic Ocean. Regional Environmental Change. 1-27.

Hamilton-Taylor, Willis, J. and Reynolds, M. C. S. (1984). Limnol. Oceanogr., 29(4), 695-710.

Khaled, A. M. M. (1997). A comparative study for distribution of some heavy metals in aquatic organismis fished from Alexandria Region. PhD. Thesis, faculty of Science, Alexandria Univ.

Malo, B. A. (1977). Environmental. Sci. Techn., 11:277-282.

Moore, J. W. and Ramamoorthy, S. (1985). "Heavy metals in natural waters". Springer- Verlag, New York, Chapter, 3:36-39.

Peters, E. C. ; Gassman, N. J. ; Firman, J. C. ; Richmonds, R. H. and Power, E. A. (1997). Ecotoxicology of tropical marine ecosystems. Environ. Toxicology and Chem., 16: 12-40.

Queirazza, G. ; Guzzi, L. (1987). Sci. Tot. Environ., 64: 191-209.

Ravanelli, M. ; Tubertini, O. ; Valeher, S. and Martinotti, W. (1997). Heavy metal distribution in sediment cores from western Ross sea (Antactica). Water Air. Soil Poll., 99: 697-704.

Salomons, W. F. and Forstner, U. (1980). Environ. Technol. Lett., l: 506-518.

Tran, Y. T. ; Barry, D. A. and Bajracharya, K. (2002). Cadmium desorption in sand. Environ. Inter., 28: 493-502.

Trefry, J. H. and Metz, S. (1984). Anal. Chem., 56: 745. 
Voutsinou-Taliadouri, F. ; Zeri, c. and Moriki, A. (2000). Distribution and transfer of trace metals in the Aegean seawater (Eastern Mediterranean Basin). Med. Mar. Sci. 1/2: 5-30.

Xintaras, C. (1992). Analysis paper: Impact of lead contaminated soil on public health, published by the U.S. department of health and human services, Agency for toxic substances and disease Registy, Atlanta, Georgia 30333, U.S.A. 


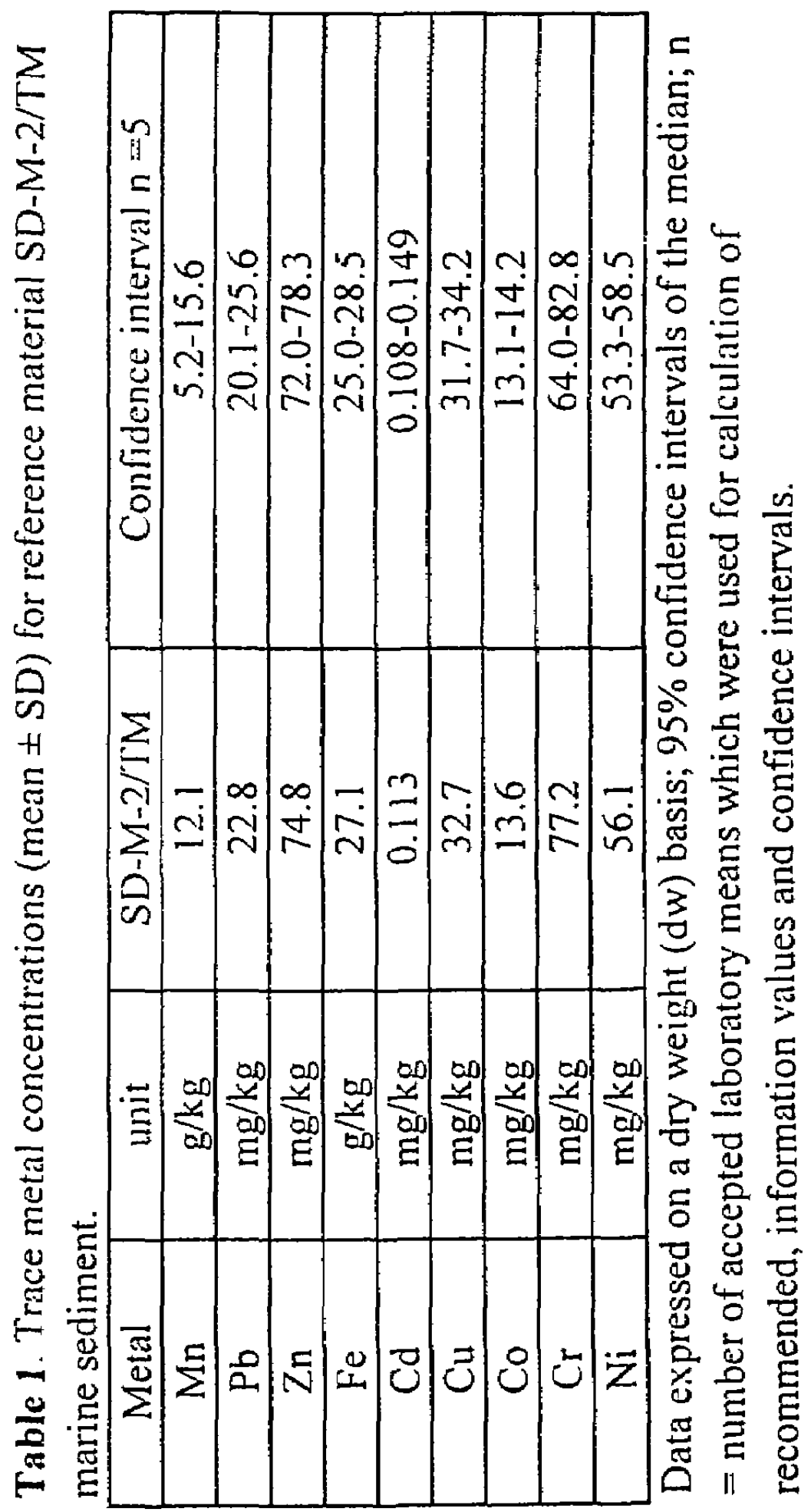




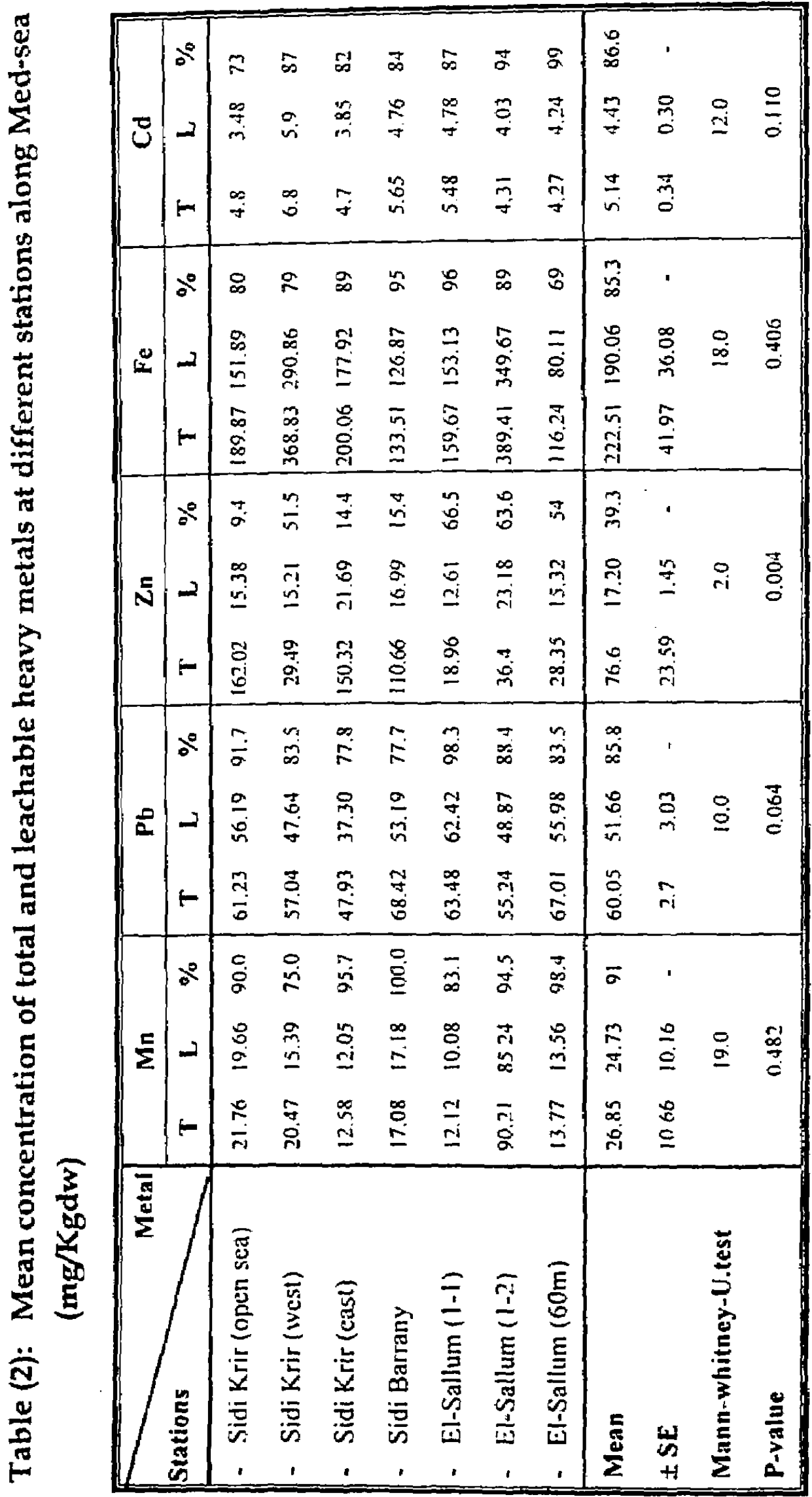




\section{TO HEAVY METALS POLLUTION}

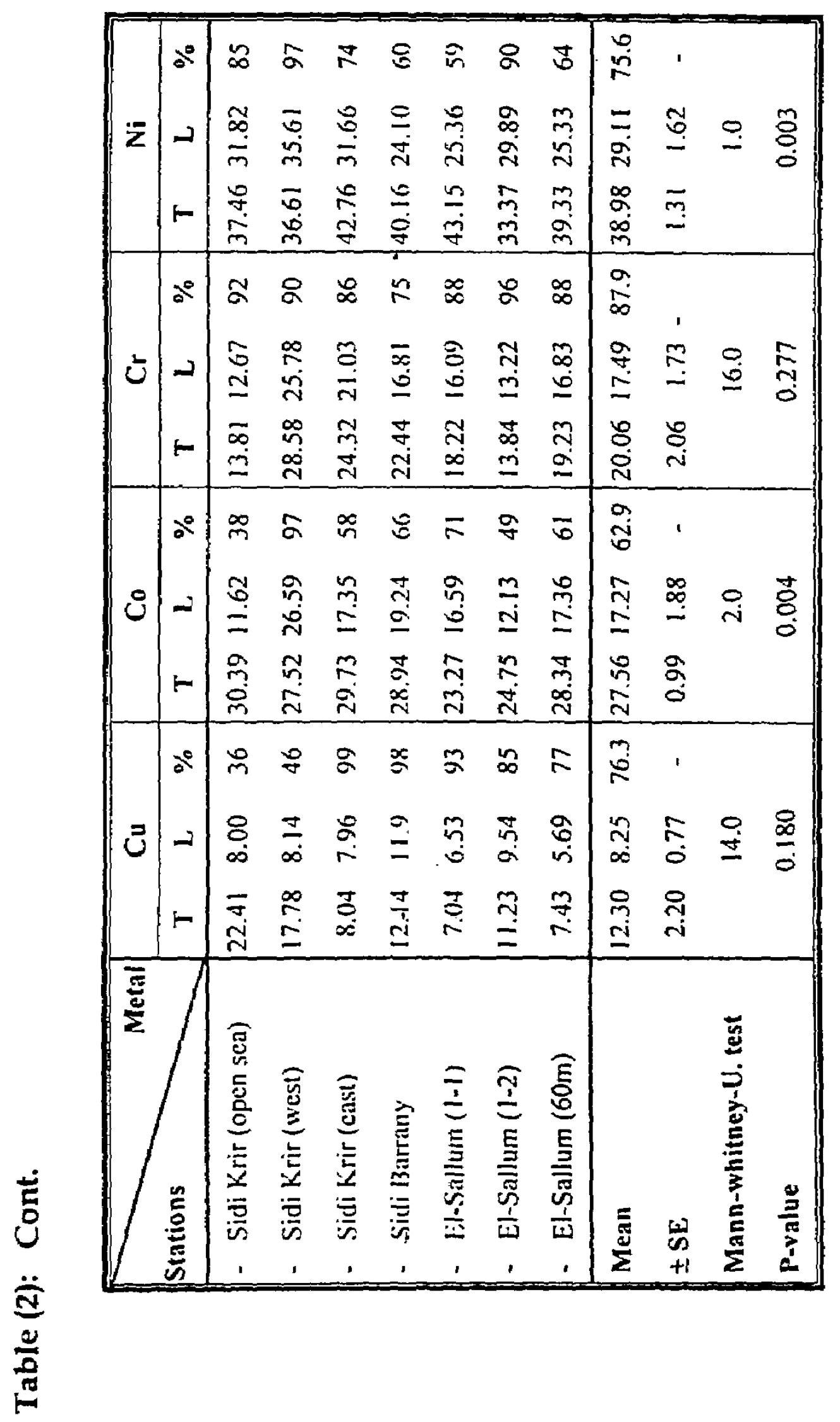




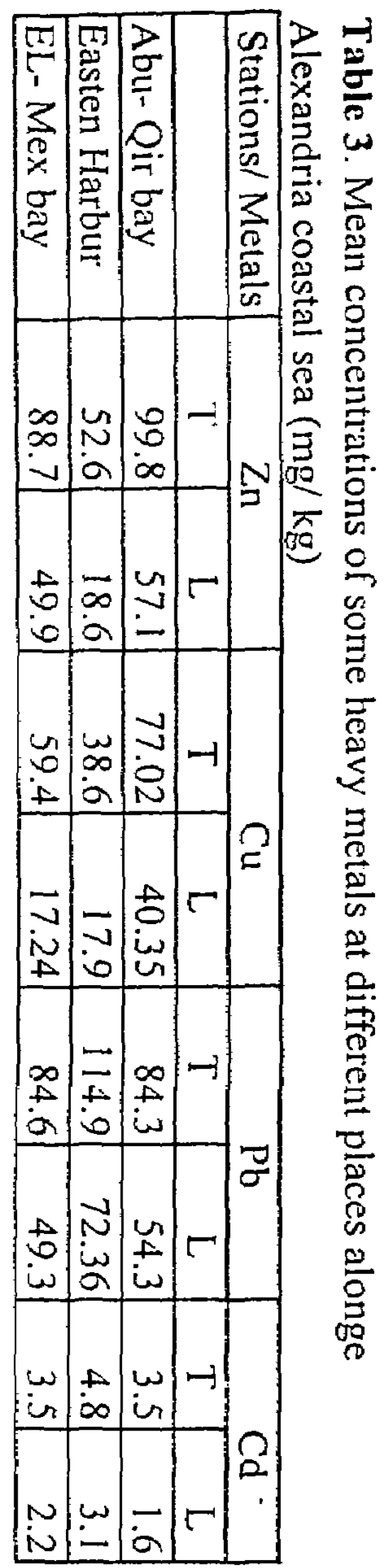




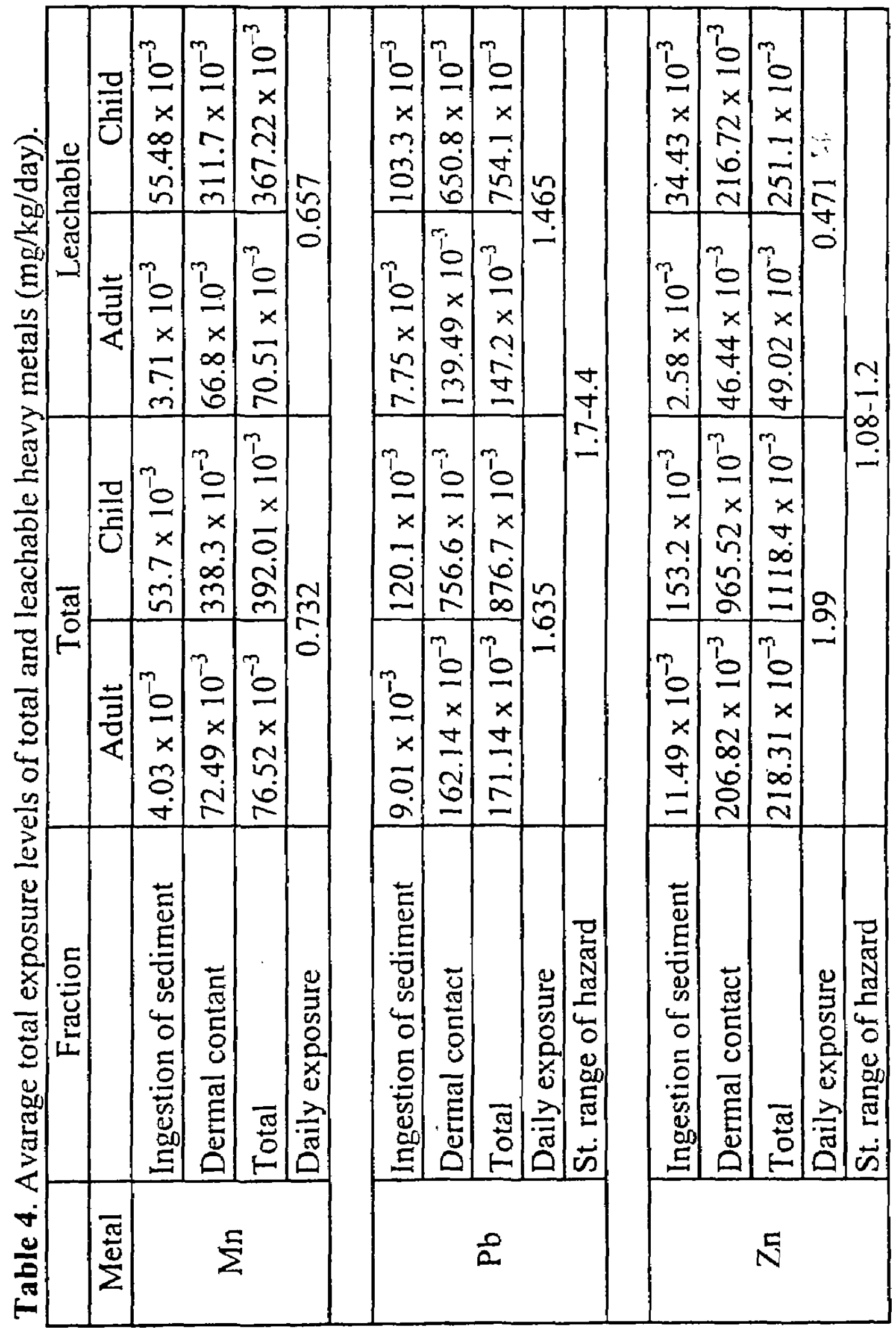




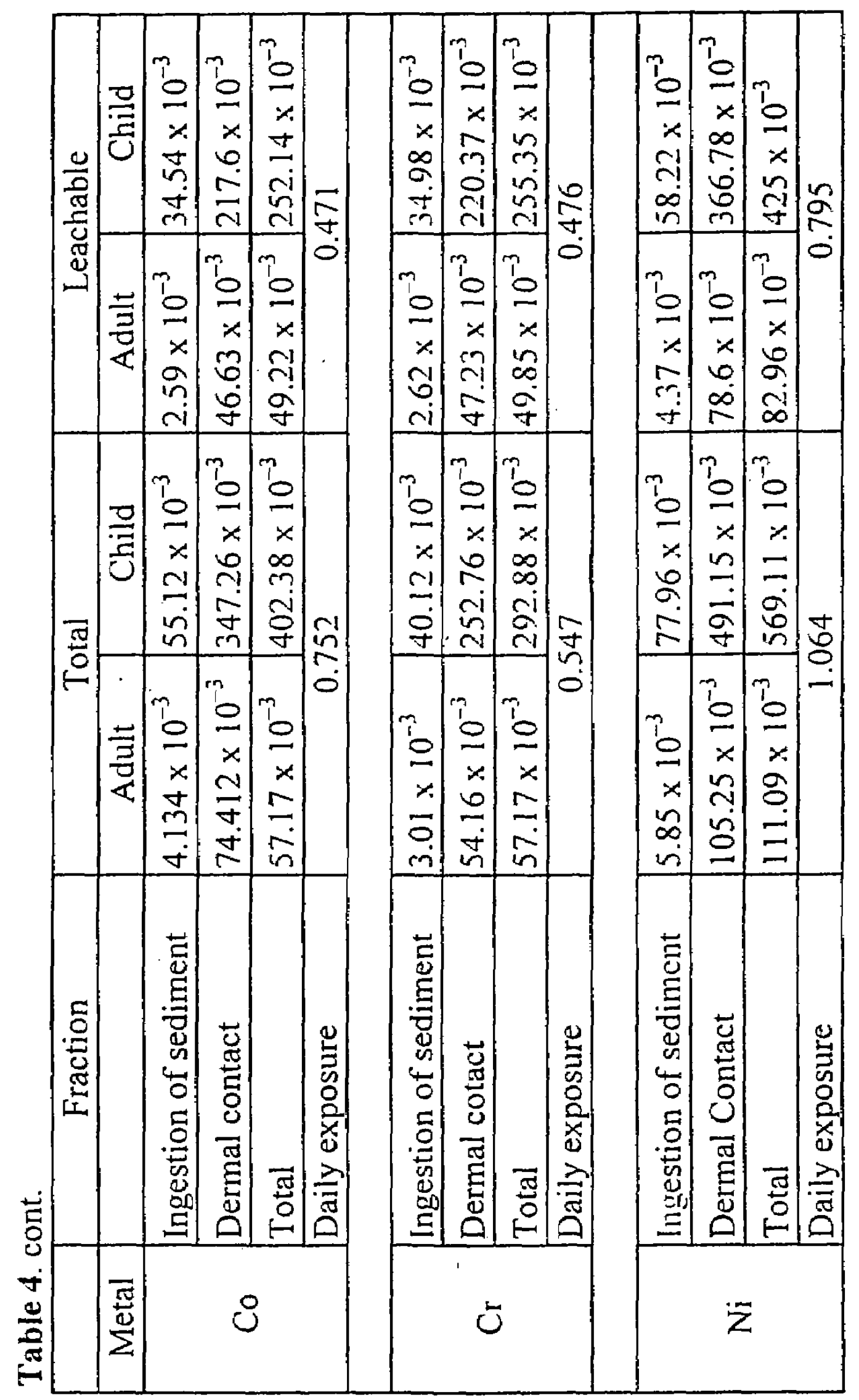




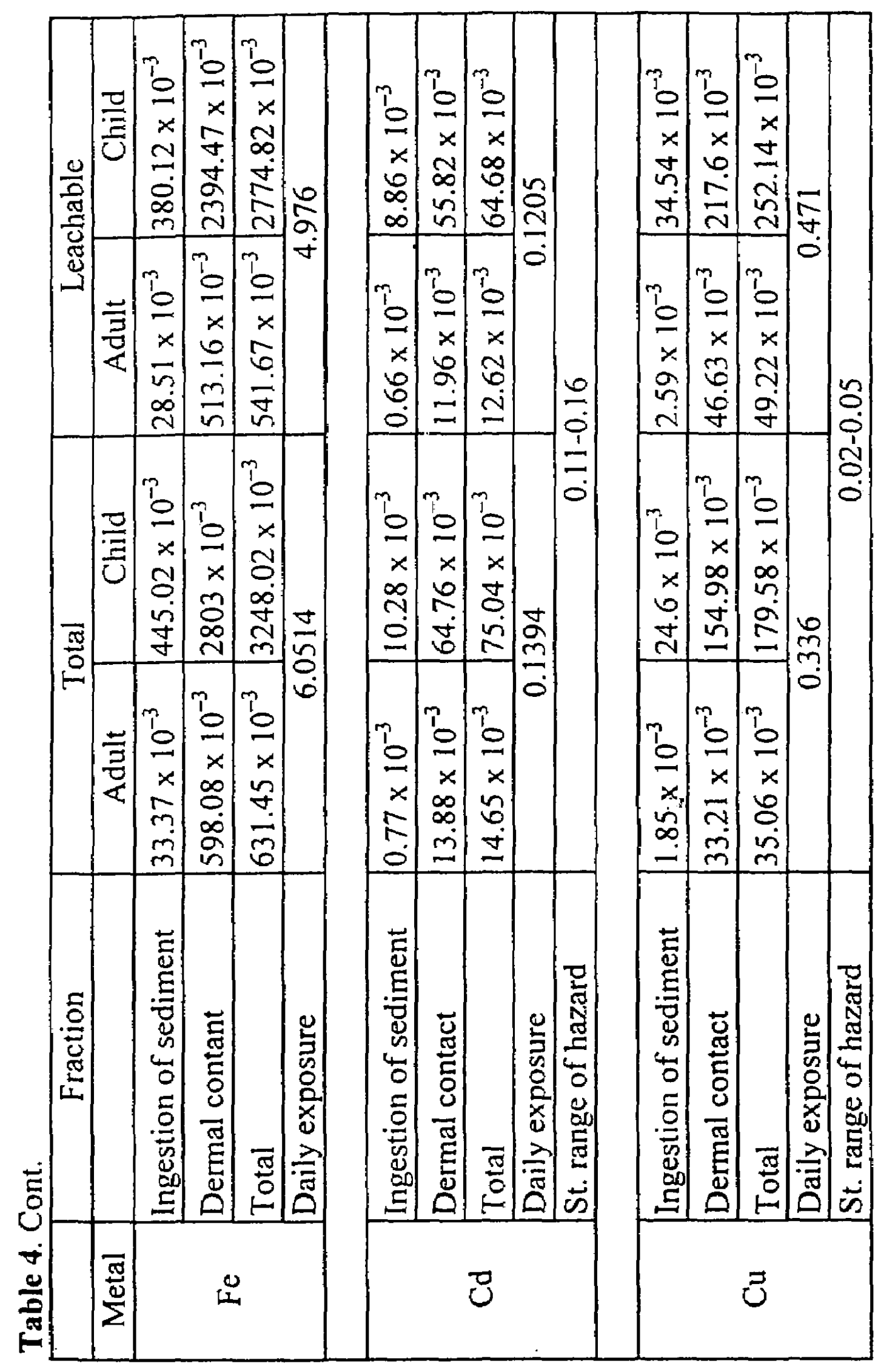




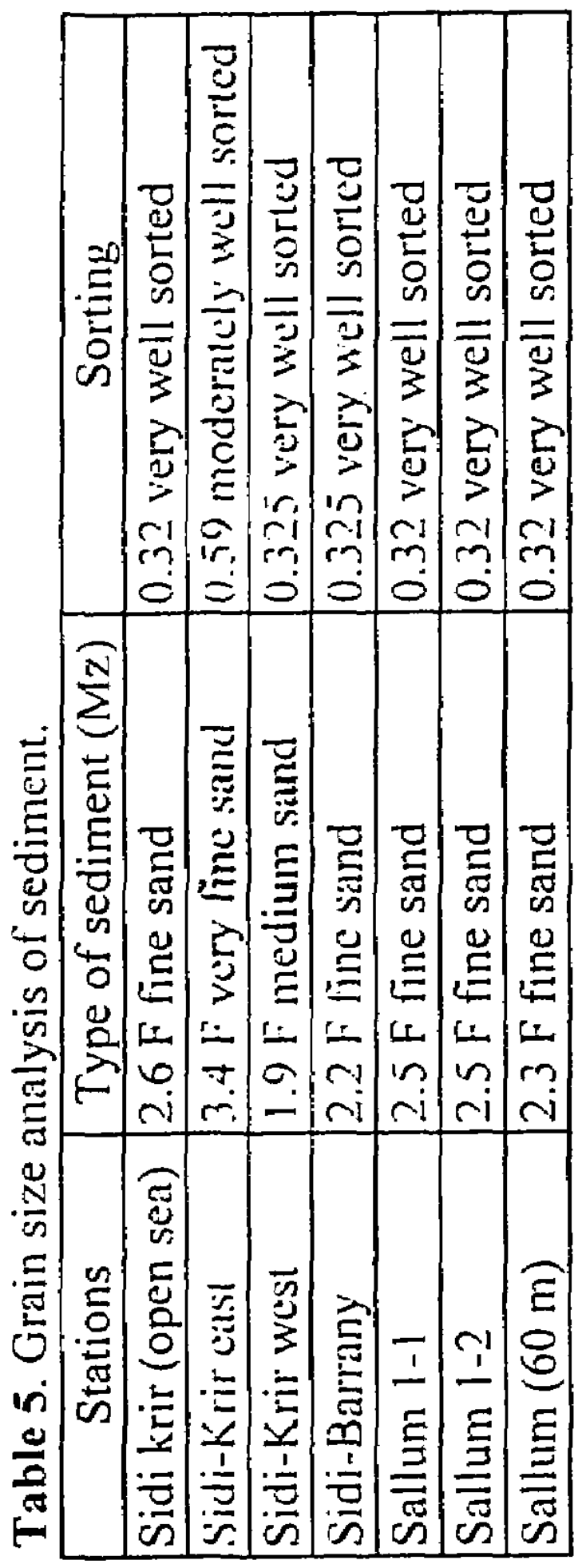




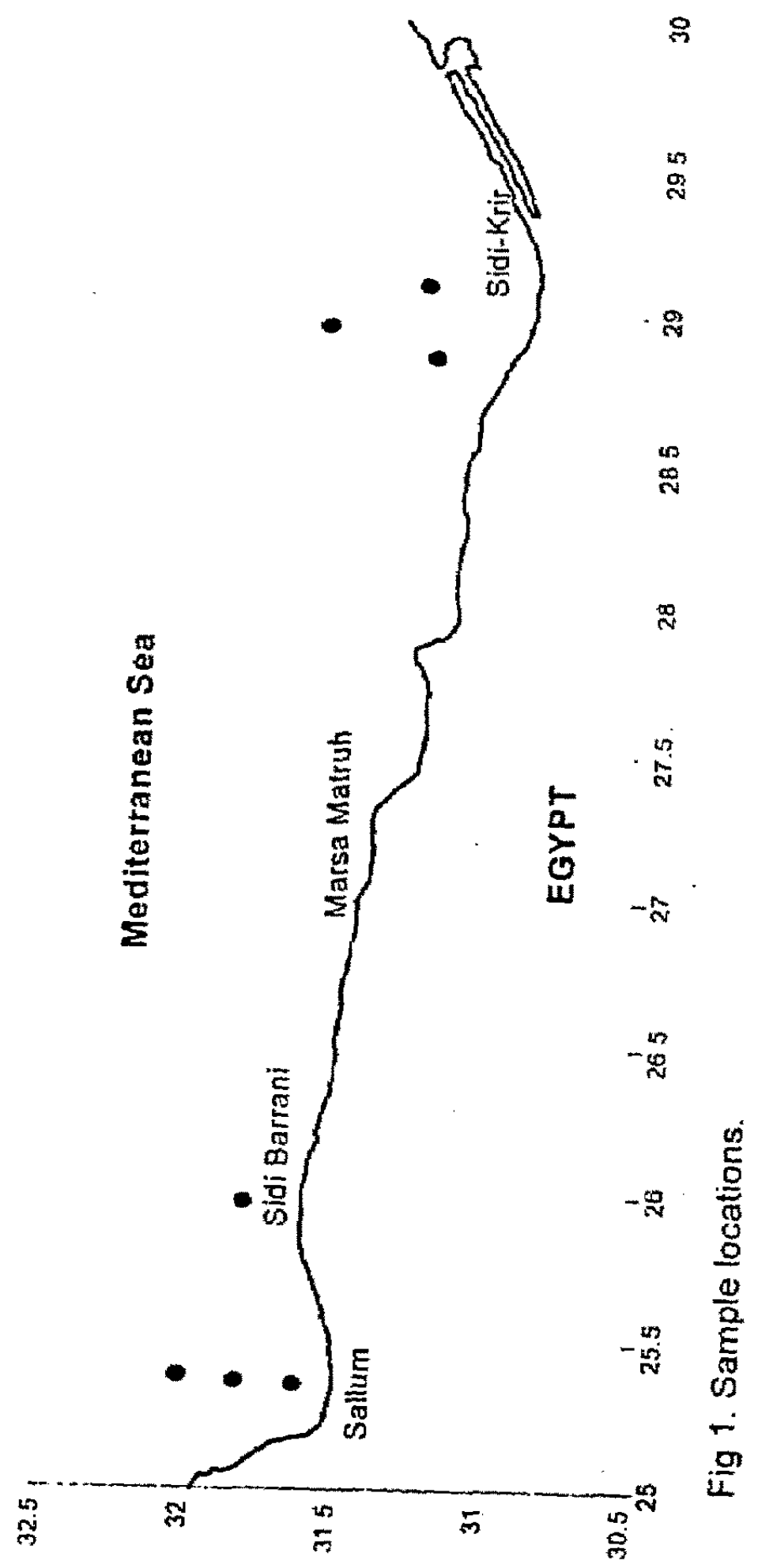




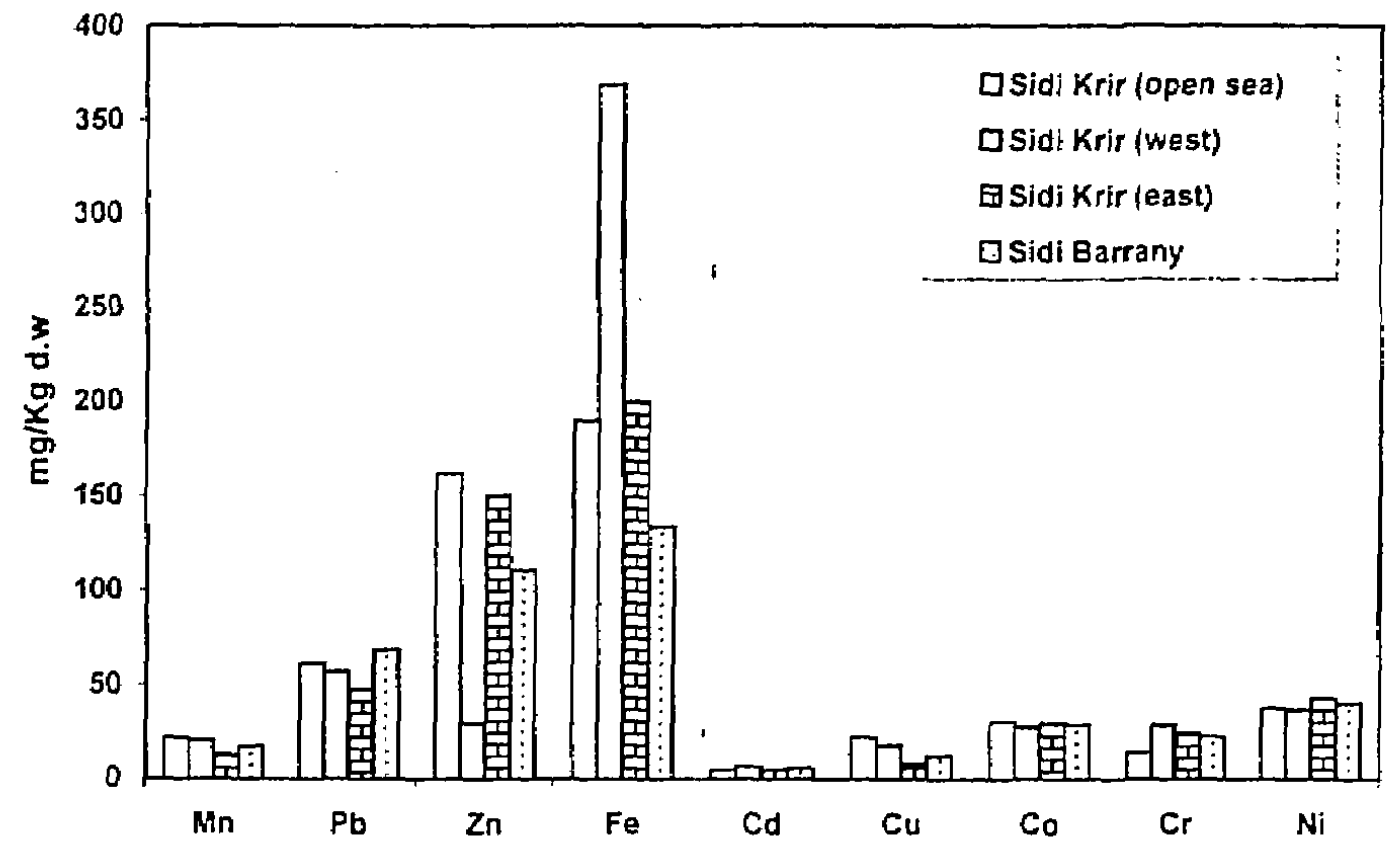

Fig $\{2-a\}$ : Concentration of total henvy metals (mg/kg d.w) in sediment samples from Sidi kirir region. The statistical significance of differences were evaluated by the Mann-Whitney-test

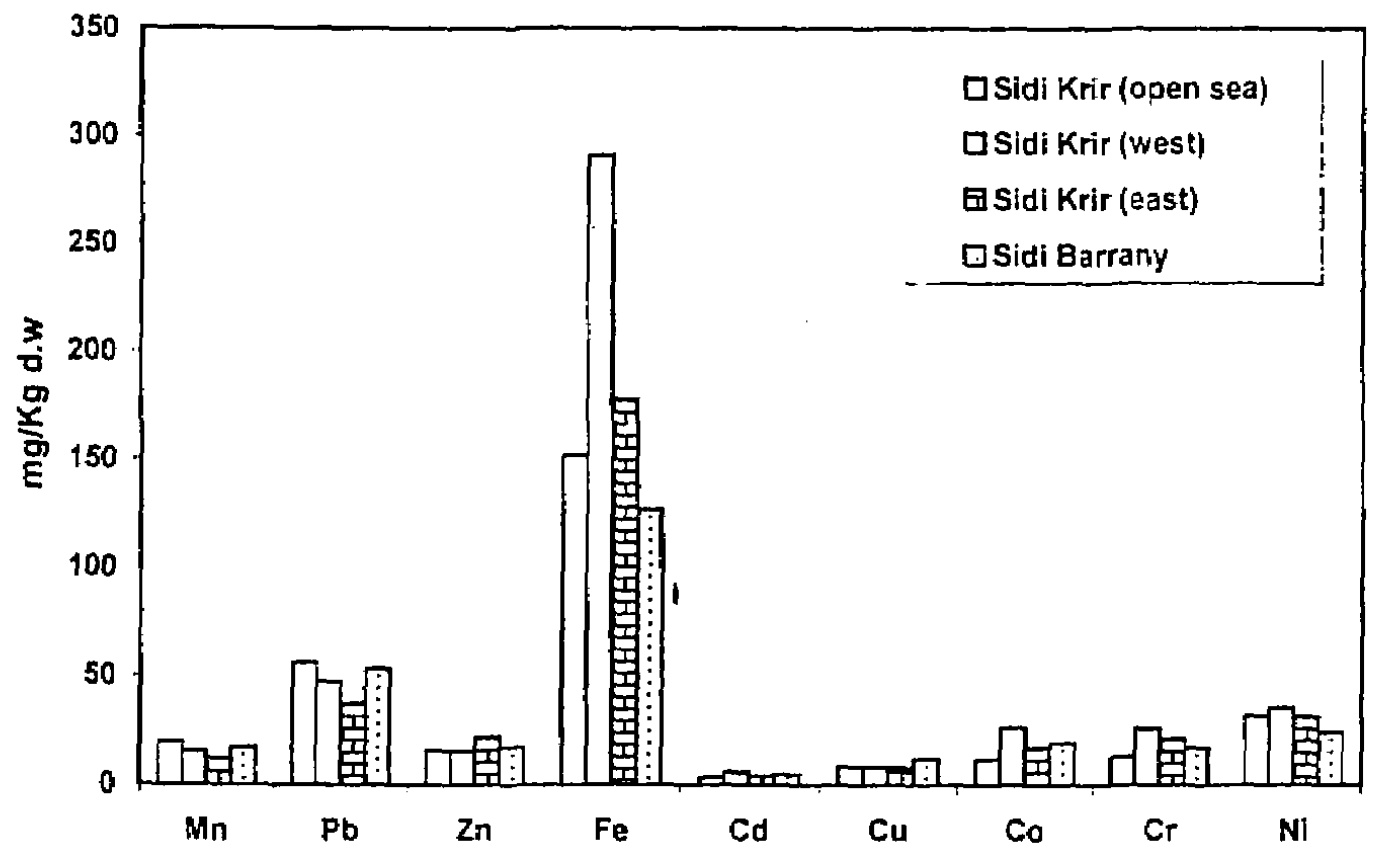

Fig (2-b) : Concentration of leachable heavy metals (mg/Kg d.w) in sediment samples from Sidi Krit region. The statistical significance of differences were evaluated by the Mann-Whitney-test 


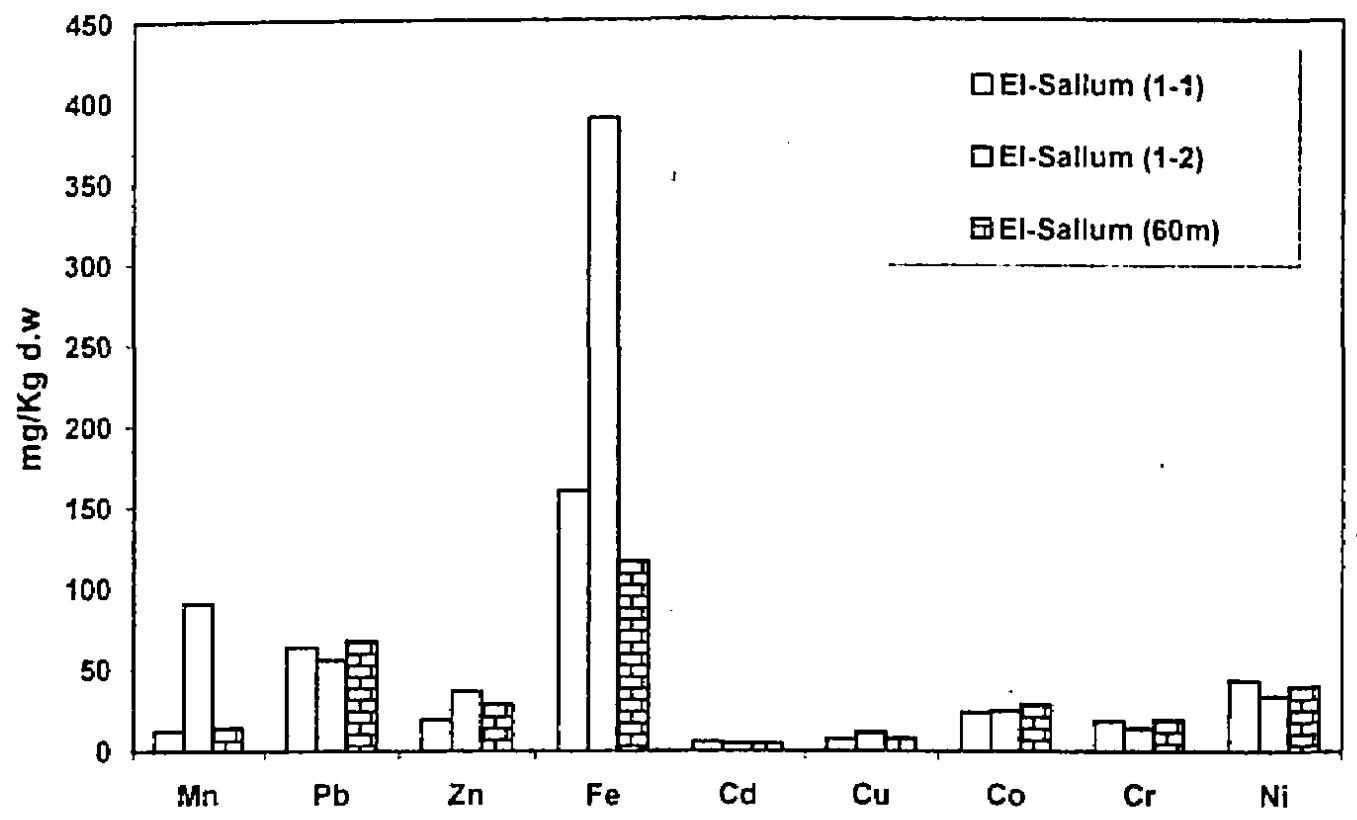

Fig (3-a) : Concentration of total heavy metals ( $\mathrm{mg} / \mathrm{Kg} \mathrm{d.w)} \mathrm{in} \mathrm{sediment}$ samples from Salum region. The statistical significance of differences were evaluated by the Mann-Whitney-test

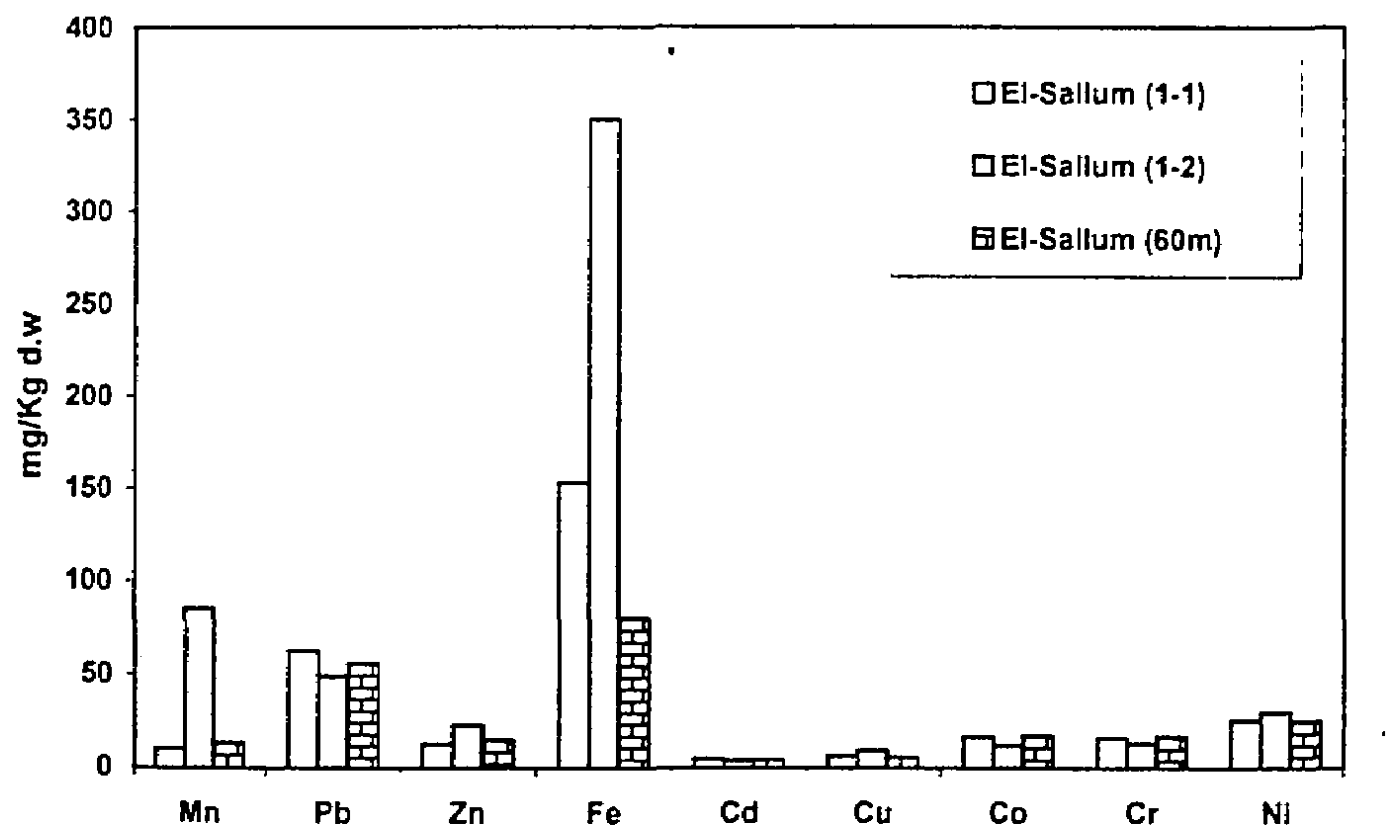

Fig (3-b) : Concentration of leachable heavy metals (mg/Kg d.s) in sediment samples from Salum region. The statistical significance of differences were evaluated by the Mann-Whitney-test 